\title{
Consensus-Based Rock Glacier Inventorying in the Torngat Mountains, Northern Labrador
}

\author{
Robert G. Way, Ph.D., ${ }^{1}$ Yifeng Wang, M.Sc., ${ }^{2}$ Alexandre R. Bevington, M.Sc., ${ }^{3}$ \\ Philip P. Bonnaventure, Ph.D., ${ }^{4}$ Jake R. Burton, B.Sc., ${ }^{5}$ Emma Davis, Ph.D., ${ }^{6}$ \\ Madeleine C. Garibaldi, M.Sc., ${ }^{7}$ Caitlin M. Lapalme, M.Sc., ${ }^{8}$ \\ Rosamond Tutton, M.Sc., 9 and Mishélle A.E. Wehbe, B.A. ${ }^{10}$
}

${ }^{1}$ Assistant Professor, Northern Environmental Geoscience Laboratory, Department of Geography and Planning, Queen's University (corresponding author). Email: robert.way@ queensu.ca

${ }^{2}$ Northern Environmental Geoscience Laboratory, Department of Geography and Planning, Queen's University. Email: yifeng.wang@queensu.ca

${ }^{3}$ British Columbia Ministry of Forests, Lands, Natural Resource Operations and Rural Development. Email: alexandre.bevington@gov.bc.ca

${ }^{4}$ Bonnaventure Lab for Permafrost Science, Department of Geography and Environment, University of Lethbridge. Email: philip.bonnaventure@uleth.ca

${ }^{5}$ Parks Canada. Email: jake.burton@canada.ca

${ }^{6}$ School of Environment, Resources and Sustainability, Environment 2, University of Waterloo. Email: emma.davis@uwaterloo.ca

${ }^{7}$ Bonnaventure Lab for Permafrost Science, Department of Geography and Environment, University of Lethbridge. Email: madeleine.garibaldi@uleth.ca

${ }^{8}$ Independent Researcher. Email: caitlin.lapalme@gmail.com

${ }^{9}$ Northern Environmental Geoscience Laboratory, Department of Geography and Planning, Queen's University. Email: 18rjt4@queensu.ca

${ }^{10}$ Bonnaventure Lab for Permafrost Science, Department of Geography and Environment, University of Lethbridge. Email: mishelle.wehbe@uleth.ca

This manuscript has undergone peer-review and has been accepted for publication in the American Society of Civil Engineers Proceedings for the 2021 Regional Conference on Permafrost and the $19^{\text {th }}$ International Conference on Cold Regions Engineering. Please feel free to contact the corresponding author with any questions or feedback. 


\begin{abstract}
The Torngat Mountains of northern Labrador are an Arctic cordilleran mountain range located at the southern limit of the Canadian Arctic. Sparse observations of periglacial landforms including rock glaciers and ice-cored moraines imply that permafrost may be widespread, but limited in situ information is available for the region. In this study, we provide the first comprehensive feature inventory of intact rock glaciers in the Torngat Mountains of northeast Canada. Prospective features were identified by a team of eight independent mappers using high-resolution satellite imagery. The initial inventory was re-assessed via consensus-building and review stages, resulting in a final inventory of 608 rock glaciers. Rock glaciers were distributed from $\sim 58^{\circ} \mathrm{N}$ to $\sim 60^{\circ} \mathrm{N}$ and were primarily concentrated in the northern end of the Torngat Mountains National Park with southern clusters located in high relief coastal mountains near $59^{\circ} \mathrm{N}$. The use of a large mapping team and the multistage consensus-based approach maximized feature inclusion and reduced misinterpretation of other features (e.g., debris-covered glaciers, ice-cored moraines, and talus couloirs) for rock glaciers. Our results show the efficacy of consensus-based landform identification for geomorphological mapping in the heterogeneous environment of the Torngat Mountains.
\end{abstract}

\title{
INTRODUCTION
}

Rock glaciers are key indicators of contemporary and past permafrost conditions (Humlum 1998) and are amongst the most recognizable permafrost landforms in mountain environments (Haeberli et al. 2006). Recent studies show that rock glaciers exhibit complicated kinematic responses to climate change (Eriksen et al. 2018; Scotti et al. 2017; Sorg et al. 2015) but can be associated with geocryological hazards (Marcer et al. 2020) and can distribute large quantities of freshwater into local ecosystems (Jones et al. 2019b). Further, rock glaciers are of significant ecological importance as they provide long-term cold habitat for local biodiversity (Brighenti et al. 2020). Numerous studies have used rock glaciers to inform interpretations of past or present permafrost distributions in areas where in situ observations of permafrost conditions are limited (Fernandes et al. 2017; Lilleøren et al. 2013; Marcer et al. 2017; Sattler et al. 2016; Schmid et al. 2015).

Debate remains over the utility of rock glaciers as permafrost indicators because they can extend well-beyond the lower elevation limits of discontinuous permafrost (Jones et al. 2019b). Interpreting geocryologically significant landforms like rock glaciers is also challenged by their similar morphology to other landforms found in periglacial environments, including protalus ramparts and periglacial creep phenomena. Inherent uncertainty in the classification of rock glaciers is also relevant for glacier-connected rock glaciers which are difficult to differentiate from debris-covered glacier termini, ice-cored moraines, and ice-cored debris fields (Jones et al. 2019a; Monnier and Kinnard 2015). There are presently no definitive visual criteria for identifying rock glaciers from imagery, though standards are in development (IPA Action Group: Rock glacier inventories and kinematics 2020). Remote sensing studies by Paul et al. (2013) and Brardinoni et 
al. (2019) demonstrated that mapped outlines of debris-covered glaciers and rock glaciers in mountainous environments could vary considerably between mappers. These studies highlight that in addition to kinematic information (e.g., interferometry, image matching; Liu et al. 2013; Villarroel et al. 2018), the inclusion of multiple operators may increase the rate of geomorphological landform detection in complex terrain.

In the Torngat Mountains of northern Labrador, modelling studies suggest that permafrost may be widespread (Way and Lewkowicz 2016, 2018), but field observations of local permafrost conditions are lacking. Remote sensing and field-based glacier inventorying studies identified icecored moraines and rock glaciers at several locations within the boundary of Torngat Mountains National Park (Figure 1; Way et al., 2014, 2015). A preliminary, unpublished rock glacier inventory created by a small team of mappers using SPOT5 satellite imagery identified 201 features in the region (Way 2017). These observations, albeit limited in geographic scope, emphasize the need for a better understanding of the distribution of permafrost landforms in the Torngat Mountains. In this study, we aim to generate a rock glacier feature inventory for the entire Torngat Mountains region; and to evaluate the efficacy of a multistage, consensus-based rock glacier identification process in a remote topographically complex glacial-periglacial environment.

\section{STUDY AREA}

The Torngat Mountains of northern Labrador form the southern limit of Canadian Arctic ecosystems (Ponomarenko and McLennan 2010) and include the tallest mountains in eastern mainland Canada ( 1650 m a.s.l. central Selamiut Range). The regional climate is classified as polar tundra (Kottek et al. 2006; Way et al. 2017) but has experienced rapid warming over the past several decades (Barrette et al. 2020; Davis et al. 2020), causing widespread expansion of upright vegetation (Davis et al. 2020; Fraser et al. 2011, 2012) and rapid melt of local glaciers (Barrand et al. 2017; Barrette et al. 2020). Regional geomorphology has been influenced by differential erosion caused by contrasting thermal regimes of basal ice (Staiger et al. 2005). Post-glacial depositional environments include extensive deposits of marine sediments below the marine limit ( 50 m a.s.l. but variable). Distance from the Labrador Sea is a key driver of glacier elevation and distribution due to local cooling and widespread high relief in the coastal mountains (Way et al. 2014).

Little information exists on permafrost conditions in the Torngat Mountains aside from archaeological investigations along the coastline and outer islands that revealed near-surface permafrost in marine deposits (Butler 2011; Jordan 1980). Prior excavation of low-elevation gelifluction lobes and soil sampling on mountain summits provided inconsistent evidence of permafrost presence or absence (Evans and Rogerson 1988; Hendershot 1985; de Vernal et al. 1983). Permafrost was encountered during the establishment of a Parks Canada monitoring station in the central Torngat Mountains in 2010, but the installed data loggers have yet to refreeze following installation (Dr. Darroch Whitaker, Parks Canada, personal communication). Deep active layers in coarse surficial deposits and exposed bedrock found throughout the Torngat Mountains make permafrost detection difficult in the absence of geomorphic indicators. An 
unpublished rock glacier inventory derived from SPOT5 satellite imagery (see Way 2017) estimated that 201 rock glaciers were present in the Torngat Mountains, though these data were not sufficiently quality-controlled to form a full inventory. Davis et al. (2020) present the first field-based observations of permafrost in the Torngat Mountains and suggest that near-surface permafrost may not be as widespread as previously thought.

\section{METHODS}

Data Sources. All feature identification activities used Maxar (Vivid) optical satellite imagery accessed via the ArcGIS Online platform (1.2 m ground sampling distance; $\sim 8.5 \mathrm{~m}$ absolute spatial accuracy). Images ranged from summer 2010 to summer 2019 and minimized seasonal snow and cloud cover. Topographic data for the Torngat Mountains were extracted from the Canadian Digital Surface Model (CDSM) produced by Natural Resources Canada ( $20 \mathrm{~m}$ spatial resolution) and were used to determine the elevational distribution of the identified rock glacier features. The CDSM was derived from reprocessed radar interferometry data collected by the Shuttle Radar Topography Mission (Endeavour mission in 2000). Gridded air temperature data covering the Torngat Mountains (30 m resolution) were generated from the CDSM following Way et al. (2017; Figure 1a) and were used to determine the 2013-2016 mean annual air temperature at the central position of each of the identified rock glaciers in the region.

Feature Identification. The workflow followed a multistage, consensus-based feature identification process that included eight independent mappers and two independent review team members (Figure 2). Mappers ranged in academic background but most had northern field experience and held bachelor's degrees or above (two BAs or BScs, four MScs, two PhDs). Two mappers held specific expertise in satellite remote sensing, four had previously studied permafrost science (graduate level or above), and one member had visited the Torngat Mountains for permafrost investigations in 2016. The review team was composed of two members with graduatelevel permafrost science field experience in Labrador. One review team member (lead author) had completed five field seasons in the Torngat Mountains and completed regional remote sensingbased glacier and rock glacier inventories (e.g., Way et al. 2014, 2015; Way 2017). 


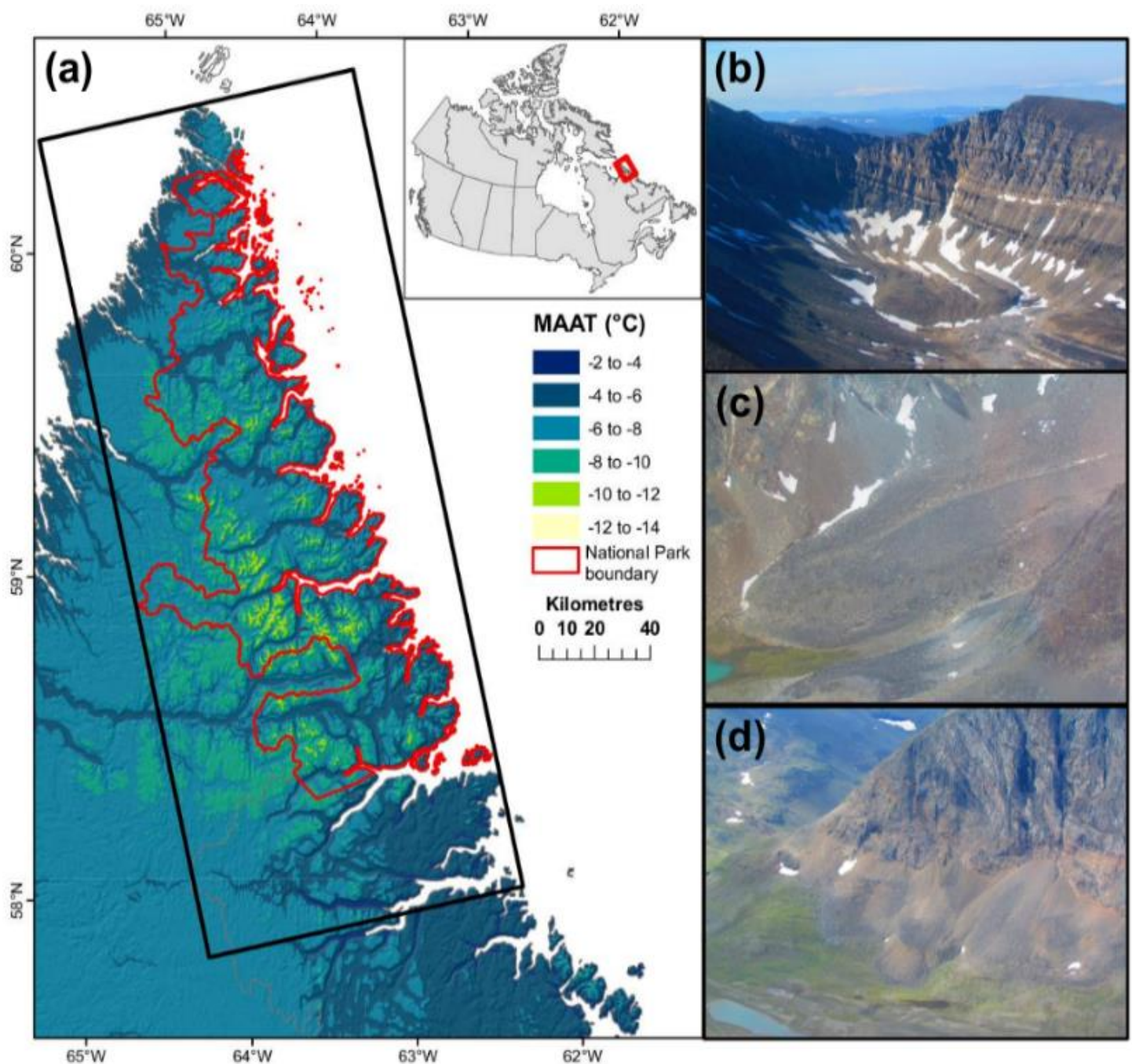

Figure 1. (a) Spatial distribution of mean annual air temperatures (2013-2016) across northern Nunatsiavut and eastern Nunavik. Bounding box (black outline) shows the extent of rock glacier inventorying activities in this study. (b) Photograph of a formerly glacierconnected rock glacier. (c) Photograph of a rock glacier tongue. (d) Photograph of a talusconnected rock glacier.

Prior to feature identification, each mapper was provided rock glacier identification training materials, video tutorials, and relevant publications. This included the International Permafrost Association Rock Glacier working group documentation on rock glacier inventorying, in which rock glaciers were defined as 'debris landforms generated by a former or current creep of frozen ground, detectable in the landscape with the following morphologies: front, lateral margins and optionally ridge-and-furrow surface topography' (IPA Action Group Rock glacier inventories and kinematics 2020). Mappers were instructed to identify prospective rock glaciers following the geomorphological approach. The prospective rock glacier inventory sought to only include features that were intact and non-relict, with geomorphological evidence of recent or former flow required for each feature (e.g., steep front, lateral margins, minimal vegetation). 
STAGE 1:

Feature Identification and Inventory Assembly

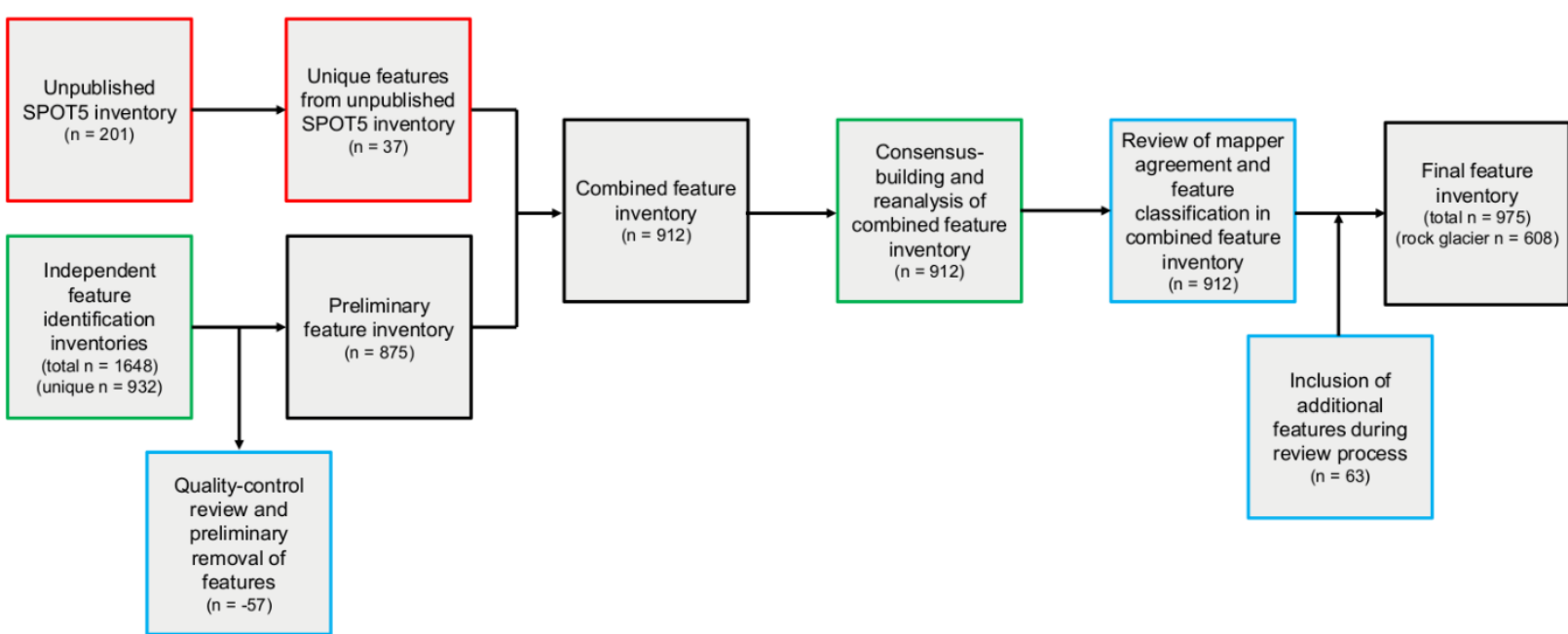

Figure 2. Conceptual diagram of the multistage consensus-building rock glacier inventorying approach used in this study.

Stage 1. The eight mappers were first asked to identify intact rock glaciers throughout the Torngat Mountains and adjacent regions (bounding box in Figure 1a). Prospective features were assigned a unique ID and a ranking from 1 (low confidence) to 3 (high confidence) to describe the mapper's confidence in their interpretation of each feature. Following the feature identification phase of stage 1, the review team compiled all eight feature inventories into a single aggregated inventory using the centre of each geomorphological feature identified by individual mappers. The mapper identification count and the confidence levels were summed for each unique feature, and the features then underwent an initial quality-control check by the review team to identify those that clearly did not meet the geomorphological criteria (e.g., folded bedrock, outcrops). The aggregated, quality-controlled stage 1 inventory was then compared by the review team to the earlier unpublished SPOT5 inventory of rock glaciers. Any features that had been previously identified in the SPOT5 inventory but had not been identified by the mapping team in stage 1 were included with the final stage 1 inventory for further review in stage 2 .

Stage 2. In stage 2, the aggregated database of stage 1 features was sent back to the mapping team for reanalysis. In this consensus-building stage, mappers were asked to indicate whether each feature was a rock glacier and to again provide accompanying confidence levels. To minimize bias, mappers were only provided a group-level confidence metric calculated as: confidence (\%) $=($ sum of indicated confidence levels $/$ maximum confidence level based on the number of identifying mappers) $x 100$. Thus, $1 / 8$ members identifying a feature as a rock glacier with a high confidence $(3 / 3=100 \%)$ would have a higher confidence than $3 / 8$ members identifying it with low confidence $(3 / 9=33 \%)$. This information was provided to guide mappers towards consensus- 
building without applying significant pressure on the mapper to conform. Upon completion of the stage 2 reanalysis by the mapping team, results were compiled by the review team.

Stage 3. Stage 3 was completed by the two-person review team. Phase 1 of this process was an initial quality-control of all features with $100 \%$ mapper agreement (i.e., 8/8 mappers rating a feature as a non-rock glacier or rock glacier). Other prospective rock glacier features that were missed in the initial inventorying process but were identified during review of nearby features were flagged by review team members and added to phase 2 for consideration. Phase 2 was a reanalysis of all remaining features (i.e., 1/8 to 7/8 mappers rating a feature as a rock glacier). Review team members independently evaluated each stage 2 feature using ArcGIS Online and ArcScene Online, while also taking mapper agreement and confidence into account. Features with conflicting classifications by the review team members were subset and subject to another independent round of evaluation. Features with persistent disagreement were assessed on a feature-by-feature basis by review team members in a joint review session using ArcScene Online. The resulting feature inventory was the final Torngat Mountains rock glacier inventory.

\section{RESULTS}

Evaluation of Feature Identification. In stage 1, mapping team members identified a total of 1648 features, of which 932 were unique. The number of features identified by individual mappers varied from 52 to 367 with a mean of 206 features. During the quality control, 57 features that corresponded to clearly folded bedrock or outcrops were removed, resulting in an aggregated inventory of 875 unique features. All the removed features had been identified by only $1 / 8$ mappers, likely reflecting mapper error. Only four of the 875 features were identified by $8 / 8$ mappers, though 100 features were identified by at least 4/8 mappers. A total of 552 features were found by only one mapper. Comparison with the unpublished SPOT5 inventory (Way 2017) showed that 164 of the 201 features $(81 \%)$ in the earlier inventory were identified by at least $1 / 8$ mappers in stage 1 . The remaining 37 features were combined with the stage 1 aggregated inventory, resulting in a combined inventory of 912 features. In stage 2, 8/8 mappers identified 168 features as rock glaciers and 116 features as non-rock glaciers. At least 4/8 mappers identified 574 features as rock glaciers, with 294 identified by at least 7/8 mappers.

During the stage 3 review process, review team member agreement was high (88\%), with only 85 features evaluated differently by the two independent reviewers. The phase 2 reanalysis resulted in 35/85 features with remaining disagreement between the reviewers, but this disagreement was rectified through a consensus-building joint review meeting. Following the stage 3 review, 548 of the original 912 features from the stage 2 database were classified as rock glaciers, and an additional 60 out of 63 prospective rock glaciers identified by the review team were added to the final inventory. The cumulative number of mappers identifying a feature as a rock glacier in stage 2 was strongly associated with it being categorized as a rock glacier at stage 3 (Figure 3). For example, the likelihood of a feature being correctly identified as a rock glacier (stage 3 output) 
in stage 2 increased from $\sim 6 \%$ to $99 \%$ for 0/8 to 8/8 mapper agreement, respectively. Comparison with the unpublished SPOT5 inventory (Way 2017) showed inclusion of 88\% (176/201) of SPOT5 rock glaciers as rock glaciers in the final inventory.

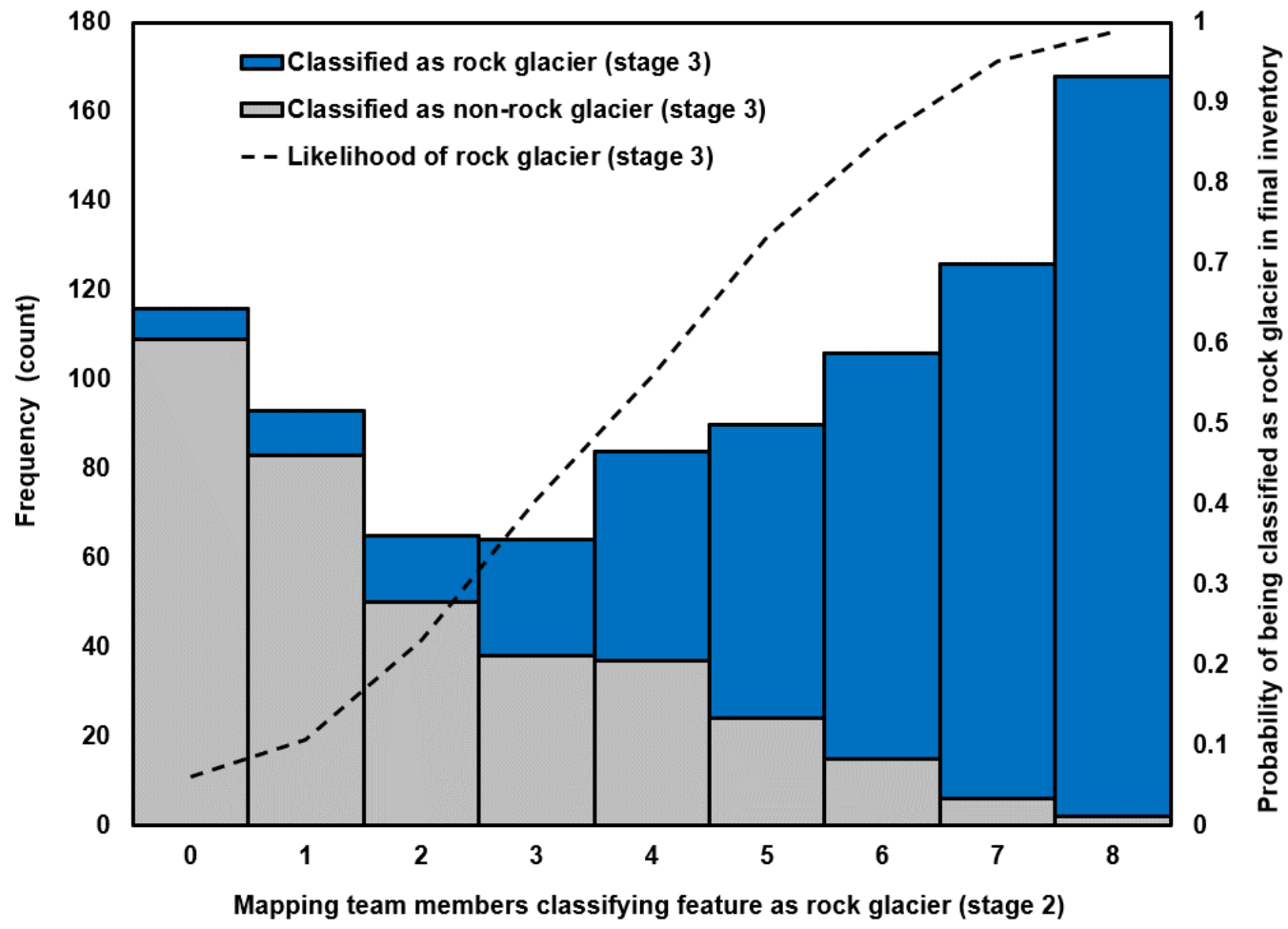

Figure 3. The number of features identified as non-rock glaciers (grey bars) and as rock glaciers (blue bars) by review team members in stage 3, stratified by the number of mappers identifying a feature as a rock glacier in stage 2 . Also shown is the probability of a feature being classified as a rock glacier in the final inventory according to the number of mappers classifying it as such in stage 2 (dashed line).

Rock Glacier Inventory Results. Six-hundred and eight rock glaciers were identified in the Torngat Mountains out of 975 prospective features ( 932 unique features identified by the mapping team and 37 from the SPOT5 inventory). Of the 608 rock glaciers, $90 \%$ originated from the stage 1 and 2 inventories whereas 60 features $(10 \%)$ were identified by the review team in stage 3 . Rock glaciers were identified as far south as $58.1^{\circ} \mathrm{N}$ and as far north as $60.3^{\circ} \mathrm{N}$, with more features in the northern half of the study area (mean latitude of $59.3^{\circ} \mathrm{N}$; Figure $4 \mathrm{a}$ ). Large clusters of rock glaciers in the southern half of the study area were typically located in fretted coastal mountains or in the central Selamiut Range (Figure 4a). The mean elevation of rock glacier centres was $\sim 430$ $\mathrm{m}$ a.s.l. though elevations ranged from $0 \mathrm{~m}$ a.s.l. to $1115 \mathrm{~m}$ a.s.l.. The elevation of rock glaciers was inversely related to latitude $\left(-158 \mathrm{~m}\right.$ per $\left.{ }^{\circ} \mathrm{N}\right)$, but the association was weak $(\mathrm{r}=0.28, p>0.01)$. Mean annual air temperatures (2013-2016) estimated for rock glacier positions ranged from $-9.7^{\circ} \mathrm{C}$ to $-3.6^{\circ} \mathrm{C}$ with a mean value of $-6.2^{\circ} \mathrm{C}$. Similar to elevation, the distribution of features according to mean annual air temperature was skewed, though to a lesser degree. 


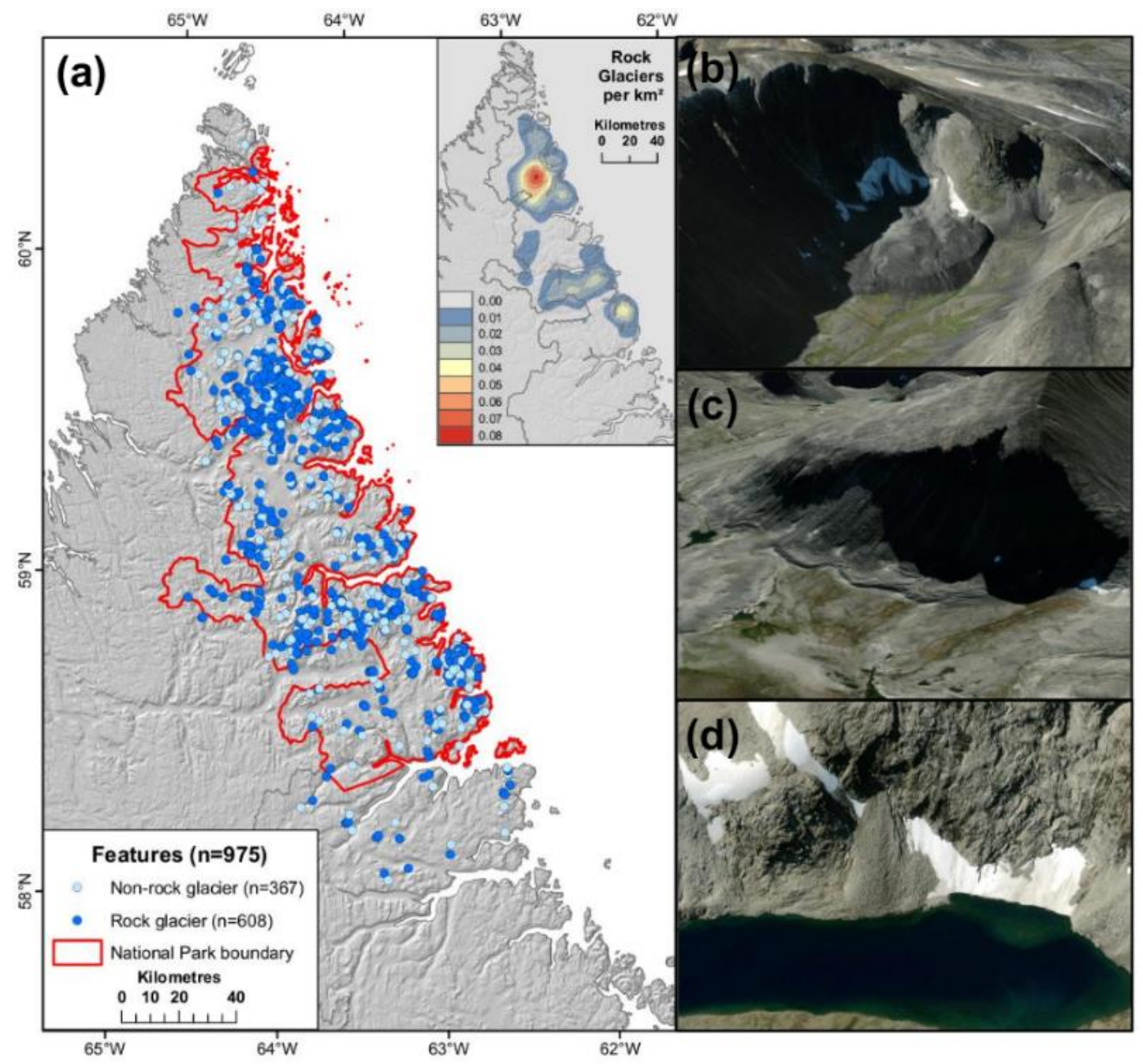

Figure 4. (a) Spatial distribution of inventoried features including rock glaciers (dark blue) and non-rock glaciers (light blue). Inset shows a kernel density map (unit: rock glaciers per $\mathbf{k m}^{2}$ ). (b) Example of glacier-connected rock glacier unit; (c) Example of talus-connected rock glacier complex; (d) Avalanche debris chute mistaken for rock glacier in stage 1. Images visualized with ArcGIS Online.

\section{DISCUSSION}

Rock Glacier Inventorying Process. The multi-stage rock glacier inventory resulted in a significantly larger feature database than those originally compiled by individual mappers (stage 1). Individual mapper inventories ranged from 52 to 367 prospective features in stage 1, whereas the final stage 3 dataset contained 608 rock glaciers. Underestimation of features in stage 1 highlights the challenges of mapping rock glaciers using optical imagery but also reflects individual sampling practices (e.g., mapper fatigue, no gridding). Notably, the earlier SPOT5 inventory was fairly accurate (176 of 201 landforms correctly identified), but it also 
underestimated the number of detectable features in the region by 432 . This may be a trade-off between SPOT5's lower spatial resolution but higher spectral resolution which favoured detection of larger, more developed features over smaller features. For this study, the use of a large mapping team facilitated the effective detection of a large number of features and likely reduced the potential rate of omitted features from the final inventory. However, $10 \%$ of the final rock glacier inventory was not identified until the final review stage, indicating the possibility that other features could be missing from the inventory. The multi-stage feature identification process also increased consensus amongst mappers from $n=4$ rock glaciers with $100 \%$ agreement in stage 1 to $\mathrm{n}=168$ in stage 2 . Further, the number of mappers identifying a feature as a rock glacier (or a non-rock glacier) at stage 2 was a strong predictor of feature inclusion at later stages (Figure 3 ). These results suggest that crowd-sourced landform identification and interpretation can improve geomorphological mapping and provide a means of assessing inventory errors in remote areas.

The review team seldomly $(n=8)$ rejected features that were identified with high agreement (> 85\%) amongst mapping team members. The limited cases of disagreement occurred when debris-covered glaciers or ice-cored moraines were misinterpreted by mappers as glacier-derived rock glaciers due to their obvious physical similarities and flow structures. These environments were challenging to interpret as they reflect the transition from glacial processes to the possible initiation of periglacial processes (e.g., creep and rock glacier initiation). Interpretation of these features was informed by past field experience working on debris-covered glaciers in the region, including field visits to some of the misclassified features (e.g., Way et al. 2014, 2015). This also highlights the value of including individuals with local knowledge/expertise on the review team. The second largest challenge was differentiating between talus-derived rock glaciers, talus couloirs, and protalus ramparts, particularly given that talus couloirs often have a lobate appearance with indications of downslope creep. Many of these features may in fact be rock glaciers, but corresponding kinematic data would be required to confirm this hypothesis. For similar reasons, it was deemed implausible to include relict rock glaciers in the inventory because of difficulty distinguishing these features from historical moraines and protalus ramparts found throughout the Torngat Mountains (André 1986).

Rock Glaciers and Permafrost in the Torngat Mountains. The inventory presented in this study suggests that rock glaciers are widespread throughout the Torngat Mountains, with increasing frequency towards the north and regional southern clusters along high relief coastal mountains. The weak decreasing trend in rock glacier elevation with latitude can be attributed to widespread permafrost distribution but could also be a result of terrain factors including changes to slope suitability for rock glacier formation. However, abundant talus-connected rock glaciers, and the lower overall elevation in the northern end of the Torngat Mountains could be indicative of more widespread near-permafrost conditions compared to regions farther south where features were often proximal to glaciers or former glacier cirques. Strictly speaking, the presence of prominent Little Ice Age moraines in many of the foregrounds of the small glaciers of the Torngat Mountains may also be indicative of the preservation of interior glacial ice (Way et al. 2015). Together, these 
observations suggest that mountain permafrost is widespread in the Torngat Mountains, but given the relatively low mean elevation of rock glaciers ( $430 \mathrm{~m}$ a.s.1.), it is difficult to determine whether the regional limits of permafrost distribution follow clear elevational boundaries.

\section{CONCLUSION}

In this study, we presented the first comprehensive feature inventory of rock glaciers in the Torngat Mountains of northern Labrador. Using a multistage consensus-based inventorying approach, we identified a total of 608 rock glaciers distributed across the Torngat Mountains (from $58.1^{\circ} \mathrm{N}$ to $60.3^{\circ} \mathrm{N}$ and a mean latitude of $59.3^{\circ} \mathrm{N}$ ). The mean elevation of rock glacier centres was $\sim 430 \mathrm{~m}$ a.s.l., ranging from $0 \mathrm{~m}$ a.s.l. to $1115 \mathrm{~m}$ a.s.l. Consensus-building steps were shown to dramatically improve the overall quality of the feature inventory while multiple $(n=8)$ mappers ensured that most of the prospective features $(\sim 90 \%)$ were identified. The results of this study highlight the value in involving larger teams in multistage, crowd-sourced remote sensing feature identification in complex environments like the Torngat Mountains. Detailed field investigations and kinematic information would be required to refine the existing Torngat Mountain rock glacier inventory.

\section{ACKNOWLEDGEMENTS}

The authors would like to acknowledge the Inuit of Nunatsiavut and Nunavik and the Torngat Mountains Cooperative Management Board for supporting research conducted on Inuit lands. The authors would like to thank the Nunatsiavut Government and Parks Canada for direct logistical, financial, and personnel support for this study. We would like to acknowledge Gary Baikie, Dr. Darroch Whitaker, and Jacko Merkuratsuk for their support of glacier and permafrost research activities in the Torngat Mountains. Thank you to our bear guards (Andreas Tuglivina, Boonie Merkuratsuk, Eli Merkuratsuk, John Merkuratsuk) who kept us safe over five field seasons conducting research in Torngats. We would also like to thank Rodd Laing, Carla Pamak, Liz Pijogge, and Dr. Paul McCarney for their logistical and permitting support for activities undertaken in Nunatsiavut. Dr. Antoni Lewkowicz and Alexander Brooker aided with an earlier version of the inventory completed with SPOT5 imagery. The authors would like to acknowledge ArcticNet Inc., Queen's University, the Royal Canadian Geographical Society, the Natural Sciences and Engineering Research Council of Canada, the W. Garfield Weston Foundation, the Association of Canadian Universities for Northern Studies, and the Canadian Polar Commission for supporting glacier and permafrost research activities of authors of this study in the Torngat Mountains. 


\section{REFERENCES}

André, M. (1986). "Types of slope evolution and dynamics in the Canadian shield of Northern Labrador." Polar Geogr. Geol., 10(1), 55-79.

Barrand, N. E., Way, R. G., Bell, T., and Sharp, M. J. (2017). "Recent changes in area and thickness of Torngat Mountain glaciers (northern Labrador, Canada)." The Cryosphere, 11(1), 157-168.

Barrette, C., Brown, R., Way, R. G., Mailhot, A., Diaconescu, E. P., Grenier, P., Chaumont, D., Dumont, D., Sévigny, C., Howell, S., and Senneville, S. (2020). "Nunavik and Nunatsiavut regional climate information update, second iteration." Nunavik Nunatsiavut Sci. Policy Integr. Reg. Impact Study IRIS Clim. Change Mod., P. Ropars, M. Lemay, and M. Allard, eds., ArcticNet, Québec City, Canada, 1-66.

Brardinoni, F., Scotti, R., Sailer, R., and Mair, V. (2019). "Evaluating sources of uncertainty and variability in rock glacier inventories." Earth Surf. Process. Landf., 44(12), 2450-2466.

Brighenti, S., Hotaling, S., Finn, D. S., Fountain, A. G., Hayashi, M., Herbst, D., Saros, J. E., Tronstad, L. M., and Millar, C. I. (2020). "Rock glaciers and related cold rocky landforms: Overlooked climate refugia for mountain biodiversity." Global Change Biol.

Butler, D. H. (2011). "Exploring soilscapes and places inside Labrador Inuit winter dwellings." Can. J. Archaeol., 35(1), 55-85.

Davis, E., Trant, A., Hermanutz, L., Way, R. G., Lewkowicz, A., Siegwart Collier, L., Cuerrier, A., and Whitaker, D. (2020). "Plant-environment interactions in the low Arctic Torngat Mountains of Labrador." Ecosystems, DOI: 10.1007/s10021-020-00577-6.

Eriksen, H. Ø., Rouyet, L., Lauknes, T. R., Berthling, I., Isaksen, K., Hindberg, H., Larsen, Y., and Corner, G. D. (2018). "Recent Acceleration of a Rock Glacier Complex, Ádjet, Norway, Documented by 62 Years of Remote Sensing Observations." Geophys. Res. Lett., 45(16), 8314-8323.

Evans, D. J., and Rogerson, R. J. (1988). "A radiocarbon-dated gelifluction lobe in the Nachvak Fiord area, northern Labrador, Canada." Earth Surf. Process. Landf., 13(7), 657-662.

Fernandes, M., Palma, P., Lopes, L., Ruiz-Fernández, J., Pereira, P., and Oliva, M. (2017). "Spatial distribution and morphometry of permafrost-related landforms in the Central Pyrenees and associated paleoclimatic implications." Quat. Int.

Fraser, R. H., Olthof, I., Carrière, M., Deschamps, A., and Pouliot, D. (2011). "Detecting longterm changes to vegetation in northern Canada using the Landsat satellite image archive." Environ. Res. Lett., 6(4), 045502.

Fraser, R., McLennan, D., Ponomarenko, S., and Olthof, I. (2012). "Image-based predictive ecosystem mapping in Canadian arctic parks." Int. J. Appl. Earth Obs. Geoinformation, 14(1), 129-138.

Haeberli, W., Hallet, B., Arenson, L., Elconin, R., Humlum, O., Kääb, A., Kaufmann, V., Ladanyi, B., Matsuoka, N., Springman, S., and Mühll, D. V. (2006). "Permafrost creep and rock glacier dynamics." Permafr. Periglac. Process., 17(3), 189-214. 
Hendershot, W. H. (1985). "Comparison of Canadian and American classification systems for some arctic soils of the Ungava-Labrador Peninsula." Can. J. Soil Sci., 65(2), 283-291.

Humlum, O. (1998). "The climatic significance of rock glaciers." Permafr. Periglac. Process., 9(4), 375-395.

IPA Action Group Rock glacier inventories and kinematics. (2020). Towards standard guidelines for inventorying rock glaciers. Baseline concepts, 1-14.

Jones, D. B., Harrison, S., and Anderson, K. (2019a). "Mountain glacier-to-rock glacier transition.” Glob. Planet. Change, 181, 102999.

Jones, D. B., Harrison, S., Anderson, K., and Whalley, W. B. (2019b). "Rock glaciers and mountain hydrology: A review." Earth-Sci. Rev., 193, 66-90.

Jordan, R. H. (1980). "Preliminary Results from Archaeological Investigations on Avayalik Island, Extreme Northern Labrador.” ARCTIC, 33(3), 607-627.

Kottek, M., Grieser, J., Beck, C., Rudolf, B., and Rubel, F. (2006). "World Map of the KöppenGeiger climate classification updated.” Meteorol. Z., 15(3), 259-263.

Lilleøren, K. S., Etzelmüller, B., Gärtner-Roer, I., Kääb, A., Westermann, S., and Guðmundsson, Á. (2013). "The Distribution, Thermal Characteristics and Dynamics of Permafrost in Tröllaskagi, Northern Iceland, as Inferred from the Distribution of Rock Glaciers and IceCored Moraines." Permafr. Periglac. Process., 24(4), 322-335.

Liu, L., Millar, C. I., Westfall, R. D., and Zebker, H. A. (2013). "Surface motion of active rock glaciers in the Sierra Nevada, California, USA: inventory and a case study using InSAR." The Cryosphere, 7(4), 1109-1119.

Marcer, M., Bodin, X., Brenning, A., Schoeneich, P., Charvet, R., and Gottardi, F. (2017). "Permafrost Favorability Index: Spatial Modeling in the French Alps Using a Rock Glacier Inventory." Front. Earth Sci., 5, 105.

Marcer, M., Rings $\varnothing$ Nielsen, S., Ribeyre, C., Kummert, M., Duvillard, P., Schoeneich, P., Bodin, X., and Genuite, K. (2020). "Investigating the slope failures at the Lou rock glacier front, French Alps.” Permafr. Periglac. Process., 31(1), 15-30.

Monnier, S., and Kinnard, C. (2015). "Reconsidering the glacier to rock glacier transformation problem: New insights from the central Andes of Chile." Geomorphology, 238, 47-55.

Paul, F., Barrand, N. E., Baumann, S., Berthier, E., Bolch, T., Casey, K., Frey, H., Joshi, S. P., Konovalov, V., Bris, R. L., Mölg, N., Nosenko, G., Nuth, C., Pope, A., Racoviteanu, A., Rastner, P., Raup, B., Scharrer, K., Steffen, S., and Winsvold, S. (2013). "On the accuracy of glacier outlines derived from remote-sensing data." Ann. Glaciol., 54(63), 171-182.

Ponomarenko, S., and McLennan, D. (2010). "Delineation and description of bioclimatic zones, Torngat Mountains National Park Reserve, Canadian Arctic.” Proc. Chang. Gradients Veg. Environ., International Association of Vegetation Science, Ensenada, Mexico, 8.

Sattler, K., Anderson, B., Mackintosh, A., Norton, K., and de Róiste, M. (2016). "Estimating Permafrost Distribution in the Maritime Southern Alps, New Zealand, Based on Climatic Conditions at Rock Glacier Sites." Front. Earth Sci., 4.

Schmid, M.-O., Baral, P., Gruber, S., Shahi, S., Shrestha, T., Stumm, D., and Wester, P. (2015). 
"Assessment of permafrost distribution maps in the Hindu Kush Himalayan region using rock glaciers mapped in Google Earth." The Cryosphere, 9(6), 2089-2099.

Scotti, R., Crosta, G. B., and Villa, A. (2017). "Destabilisation of Creeping Permafrost: The Plator Rock Glacier Case Study (Central Italian Alps): The Destabilised Plator Rock Glacier." Permafr. Periglac. Process., 28(1), 224-236.

Sorg, A., Kääb, A., Roesch, A., Bigler, C., and Stoffel, M. (2015). "Contrasting responses of Central Asian rock glaciers to global warming." Sci. Rep., 5(1), 8228.

Staiger, J. K. W., Gosse, J. C., Johnson, J. V., Fastook, J., Gray, J. T., Stockli, D. F., Stockli, L., and Finkel, R. (2005). "Quaternary relief generation by polythermal glacier ice." Earth Surf. Process. Landf., 30(9), 1145-1159.

de Vernal, A., Mathieu, C., and Gangloff, P. (1983). "Analyse stratigraphique d'un lobe de gélifluxion des Torngats Centrales, Labrador.” Géographie Phys. Quat., 37(2), 205.

Villarroel, C., Tamburini Beliveau, G., Forte, A., Monserrat, O., and Morvillo, M. (2018). "DInSAR for a Regional Inventory of Active Rock Glaciers in the Dry Andes Mountains of Argentina and Chile with Sentinel-1 Data." Remote Sens., 10(10), 1588.

Way, R. G. (2017). "Field and modelling investigations of permafrost conditions in Labrador, northeast Canada." PhD Thesis, University of Ottawa, Ottawa, Canada.

Way, R. G., Bell, T., and Barrand, N. E. (2014). "An inventory and topographic analysis of glaciers in the Torngat Mountains, northern Labrador, Canada." J. Glaciol., 60(223), 945-956.

Way, R. G., Bell, T., and Barrand, N. E. (2015). "Glacier change from the early Little Ice Age to 2005 in the Torngat Mountains, northern Labrador, Canada." Geomorphology, 246, 558569.

Way, R. G., and Lewkowicz, A. G. (2016). "Modelling the spatial distribution of permafrost in Labrador-Ungava using the temperature at the top of permafrost." Can. J. Earth Sci., 53(10), 1010-1028.

Way, R. G., and Lewkowicz, A. G. (2018). "Environmental controls on ground temperature and permafrost in Labrador, northeast Canada." Permafr. Periglac. Process., 29(2), 73-85.

Way, R. G., Lewkowicz, A. G., and Bonnaventure, P. P. (2017). "Development of moderateresolution gridded monthly air temperature and degree-day maps for the Labrador-Ungava region of northern Canada." Int. J. Climatol., 37(1), 493-508. 